\title{
Deteksi Fraud Financial Statement Menggunakan Model Fraud Pentagon pada Perusahaan yang Terdaftar di JII Tahun 2016-2018
}

\author{
Ahmad Naufal Fadhlurrahman \\ FEBI Universitas Islam Negeri Sunan Kalijaga, Yogyakarta \\ Email korespondensi: ahmadnaufalfadh@gmail.com
}

\begin{abstract}
Abstrak
Penelitian ini bertujuan untuk menganalisis proksi-proksi yang dianggap dapat mendeteksi kecurangan laporan keuangan dengan model fraud pentagon. Model ini merupakan pengembangan dari model fraud triangle dan fraud diamond dengan menambahkan elemen arogansi untuk melengkapi empat elemen terdahulu yang sudah ada, yakni tekanan, peluang, rasionalisasi, dan kompetensi. Populasi yang digunakan dalam penelitian ada perusahaan yang terdaftar pada Jakarta Islamic Index (JII) tahun 2016-2018. Sampel perusahaan yang didapatkan menggunakan teknik purposive sampling adalah 14 perusahaan dan diuji menggunakan analisis regresi berganda. Hasil yang diperoleh dari penelitian ini menunjukkan bahwa stabilitas yang di proksikan oleh perubahan total aset dan perubahan direksi sebagai proksi dari elemen kompetensi mempunyai pengaruh dalam memprediksi kecurangan laporan keuangan, sementara elemen peluang, rasionalisasi dan arogansi tidak berpengaruh terhadap kecurangan lapoan keuangan. Sehingga diharapkan penelitian ini dapat dikembangkan dengan memperpanjang tahun penelitian dan proksi yang mewakili setiap elemen dari model ini.
\end{abstract}

Kata kunci: Fraud Pentagon, Fraud Laporan Keuangan, Stabilitas, Kompetensi

\begin{abstract}
This study aims to analyze the proxies that are considered to be able to detect financial statement fraud with the pentagon fraud model. This model is a development of the fraud triangle and fraud diamond models by adding arrogance elements to complement the previous four existing elements, namely pressure, opportunity, rationalization, and competence. The population used in the study are companies listed on the 2016-2018 Jakarta Islamic Index (JII). Company samples obtained using purposive sampling technique are 14 companies and tested using multiple regression analysis. The results obtained from this study indicate that the stability proxied by changes in total assets and changes in directors as a proxy of the competency element has an influence in predicting financial statement fraud, while the opportunity, rationalization and arrogance elements do not affect financial report fraud. It is hoped that this research can be developed by extending the research years and proxies that represent each element of this model.
\end{abstract}

Keywords: Pentagon Fraud, Financial Statement Fraud, Stability, Competence

Saran sitasi: Fadhlurrahman, A. N. (2021). Deteksi Fraud Financial Statement Menggunakan Model Fraud Pentagon pada Perusahaan yang Terdaftar di JII Tahun 2016-2018. Jurnal Ilmiah Ekonomi Islam, 7(02), 10761083. doi: http://dx.doi.org/10.29040/jiei.v7i2.2566

DOI: http://dx.doi.org/10.29040/jiei.v7i2.2566

\section{PENDAHULUAN}

Laporan keuangan merupakan instrumen penting dalam operasional perusahaan karena terdapat catatan informasi akuntansi perusahaan pada periode akuntansi tertentu yang bisa mencerminkan kondisi perusahaan secara financial. Informasi ini berguna untuk manajemen perusahaan dan investor mengetahui keuntungan perusahaan dan menjadi tolak ukur kinerja perusahaan sebagai packaging manajemen perusahaan yang berpengaruh dalam aktivitas investasi di masa mendatang.

Statement of Financial Accounting Concept (SFAC) No. 1 memaparkan bahwa unsur utama dalam menilai suatu kinerja atau pertanggungjawaban manajemen dengan melihat informasi laba, sehingga dalam usahanya memberikan informasi laba yang 


\section{Jurnal Ilmiah Ekonomi Islam, 7(02), 2021, 1077}

bagus, kadang-kadang menimbulkan perilaku manajemen laba (earning management) yang dijelaskan dalam teori keagenan (agency theory) (Siddiq, Achyani, \& Zulfikar, 2017). Sehingga, tindakan earning management memunculkan beberapa kasus penipuan untuk menampilkan laporan keuangan yang memuaskan.

Kasus-kasus mengenai manipulasi laporan keuangan di luar negeri terjadi pada Xeroc, Enron, dan WorldCom yang menyebabkan publik Amerika Serikat meragukan integritas dan kredibilitas pelaku bisnis. Tak hanya di luar negeri, di Indonesia pun skandal pelaporan akuntansi pernah terjadi pada PT Kimia Farma Tbk, PT Waskita Karya Tbk, PT Kereta Api Indonesia Tbk. Kasus terbaru mengenai manipulasi laporan keuangan dilakukan PT Garuda Indonesia Tbk yang dituduh memanipulasi laporan Desember 2018, dimana tertulis bahwa PT Garuda Indonesia Tbk mendapatkan laba bersih US $\$ 809,85$ ribu atau sekitar Rp 11 miliar. Padahal, diketahui bersama bahwa perusahaan tersebut mengalami kerugian cukup dalam pada 2017 yang mencapai Rp 3 triliun (Lesmana, 2019).

Kasus-kasus yang terjadi menunjukkan bahwa pelaporan keuangan yang curang dapat merugikan berbagai pihak. Penyajian data yang tidak sesuai dengan kondisi aktual dalam laporan keuangan menyebabkan infromasi yang ditampilkan tidak relevan untuk dijadikan bahan pengambilan keputusan. Association of Certified Fraud Examiners (2016) menyebutkan bahwa Laporan keuangan yang telah dimanipulasi membuat kerugian besar bagi investor dimana mereka tidak akan mendapatkan pengembalian modal yang diinvestasikan. menyatakan bahwa pelaporan keuangan yang curang di perusahaan diduduki oleh pemilik atau eksekutif sebagai pelakukunya, diikuti oleh manajer dan karyawan sebagai pelaku manipulasi.

Kecurangan yang terjadi diperusahaan dapat dideteksi dengan teori-teori mengenai deteksi kecurangan yang telah digagas oleh penelitianpenelitian terdahulu. Beberapa teori dalam mendeteksi kecurangan diantaranya pendekatan fraud triangle (Cressey, 1953), fraud diamond (Wolfe \& Hermanson, 2004), dan yang terbaru yaitu fraud pentagon (Horwarth, 2012). Pengukuran kecurangan laporan keuangan dapat dilakukan melalui berbagai cara, salah satunya dengan menggunakan proksi earning management (Spatish, 2002). Maka, penelitian ini bertujuan untuk menganalisis faktor- faktor penentu pelaporan keuangan yang curang melalui pendekatan fraud pentagon dengan menggunakan proksi earning management (manajemen laba). Selain itu, penelitian yang menganalisis penipuan menggunakan teori fraud pentagon Crowe masih sangat sedikit (Marks, 2012).

\section{KAJIAN PUSTAKA DAN HIPOTESIS Agency Theory (Teori Keagenan)}

Agency Theory adalah sebuah kontrak dengan satu orang atau lebih (prinsipal) dengan memberikan instruksi kepada orang lain (agen) untuk melakukan jasa atas nama prinsipal, kemudian memberi agen suatu wewenang untuk pengambilan keputusan yang tepat dan terbaik untuk prinsipal. Dimana, prinsipal yang dimaksud adalah investor, sedangkan agen adalah manajemen perusahaan; manajer, staff, dan karyawan (Jensen \& Meckling, 1976). Teori Keagenan ialah teori yang menjadi landasan dasar perusahaan dan acuan bisnis, selain itu memberikan gambaran mengenai korelasi principal dengan agen (manajemen) pada perjanjian kerja sama (Nexus of contract).

\section{Earning Management (Manajemen Laba)}

Manajemen laba (Earning Management) adalah suatu spekulasi dengan menerapkan kebijakankebijakan akuntansi sebagai bentuk dari keputusan yang dilakukan oleh seorang manajer untuk mencapai tujuan tertentu (Scott, 2003) dalam (Siddiq dkk., 2017). Menurut Sugiri (1998) dalam (Siddiq dkk., 2017), earning management adalah suatu pendekatan metode akuntansi untuk mengolah komponen discretionary accrual untuk menetapkan nilai profit suatu perusahaan yang dilakukan oleh manajer.

\section{Fraud (Kecurangan)}

Albrecht dan Zimbelman (2009) mendefinisikan beberapa frauds (kecurangan). Secara umum, kecurangan ( fraud) merupakan istilah yang digunakan mencakup semua tindakan individu atau kelompok untuk mendapatkan manfaat dan keuntungan dari orang lain melalui penyajian yang salah dengan menggunakan konsep kecerdasan manusia.

\section{Teori Fraud Pentagon (Fraud Pentagon Theory)}

Model Fraud Pentagon dikembangkan oleh Horwarth (2012) yang merupakan pengembangan dari teori fraud triangle (Cressey, 1953) dan teori fraud diamond (Wolfe \& Hermanson, 2004). Horwarth (2012) mengembangkan kedua teori sebelumnya dengan merubah risk factor fraud kapabilitas (capabilty) menjadi kompetensi (competence) dan 
menambah fakor arogansi (arrogance) dalam risk factor fraud pada teorinya. Crowe juga menjelaskan bahwa ada lima unsur arogansi dari perspektif CEO: 1) Ego besar, karena CEO dipandang sebagai selebriti daripada sebagai pengusaha; 2) Mereka dapat memangkas melalui kontrol internal dan tidak tertangkap; 3) Mereka memiliki tindakan menekan (Bullying-attitude); 4) Mereka menerapkan gaya manajemen otokratis; 5) Mereka takut kehilangan jabatan atau status. Sehingga, terdapat lima elemenelemen yang menjadi unsur penyebab penipuan dalam teori fraud pentagon diantaranya sebagai berikut.

\section{a. Tekanan (pressure) dan Financial Statement Fraud}

Menurut Cressey (1953) tekanan merupakan suatu kondisi yang hadir dalam penipuan laporan keuangan. Adanya hubungan antara tekanan dan penipuan laporan keuangan telah terbukti (Skousen, 2008); (Sihombing \& Rahardjo, 2014). Tekanan muncul ketika kinerja perusahaan turun dan manajemen dapat memanipulasi laporan keuangan perusahaan untuk memberikan penampilan pertumbuhan yang stabil. Stabilitas keuangan perusahaan dapat diukur melalui pertumbuhan aset, penjualan perusahaan, dan nilai laba perusahaan per tahun (Skousen, 2008). Hasil penelitiannya menunjukkan bahwa semakin besar rasio perubahan total aset suatu perusahaan, maka adanya kemungkinan tindakan fraud pada laporan keuangan. Maka, rumusan hipotesis adalah:

H1: Stabilitas Keuangan berpengaruh terhadap financial statement fraud

\section{b. Peluang (opportunity) dan Financial Statement Fraud}

dapat menjadi penyebab penipuan laporan keuangan. Dimana perusahaan dengan kontrol internal yang lemah memiliki celah dan peluang bagi manajemen untuk memanipulasi transaksi, diperburuk dengan anggapan pelaku bahwa aktivitasnya tidak akan terdeteksi/diketahui. Dalam hal ini, kualitas auditor menjadi sangat penting bagi seorang auditor untuk mendeteksi dan melaporkan hasil auditnya. Kualitas auditor eksternal ditentukan oleh pemilihan jasa audit pada kantor akuntan publik (KAP) yang ditunjuk oleh perusahaan baik yang tergabung dalam BIG4 dan Non BIG4. Lennox dan Pittman (2010) dalam (Siddiq dkk., 2017) menemukan bahwa perusahaan audit yang tergabung dalam BIG4 mempunyai sumber daya manusia (SDM) dengan kemampuan lebih dalam mendeteksi financial statement fraud dibandingkan dengan perusahaan Non-BIG4. Apabila suatu perusahaan memiliki jasa audit eksternal yang tergabung dalam perusahaan audit BIG4 maka dapat mendeteksi terjadinya financial statement fraud. Berdasarkan uraian tersebut hipotesis yang dirumuskan adalah:

H2: Quality of External Audit berpengaruh terhadap financial statement fraud

c. Rasionalisasi (rationalization) dan Financial Statement Fraud

Rasionalisasi merupakan pelaku yang membenarkan tindakan mereka dalam melakukan penipuan (Shelton, 2014) dalam (Siddiq dkk., 2017). Rasionalisasi adalah alasan untuk pembenaran tindakan fraud dengan anggapan bahwa tindakan yang dilakukan adalah hal yang wajar. St. Pierre \& Anderson (1984) dan Stice (1991) menjelaskan bahwa rasionalisasi dapat diproksikan dengan perubahan auditor dikarenakan adanya upaya penghapusan jejak audit mengenai penemuan fraud pada audit sebelumnya. Berdasarkan penelitian (Skousen, 2008), Rationalization dapat diukur dengan menggunakan proksi pergantian atau perubahan kantor akuntan publik (KAP). Berdasarkan uraian tersebut hipotesis yang dirumuskan adalah:

H3: Change in auditor berpengaruh terhadap financial statement fraud

d. Kompetensi (competence) dan Financial Statement Fraud

Kompetensi dapat dijelaskan sebagai keahlian seseorang (karyawan) untuk mengabaikan kontrol internal, mengembangkan strategi penyembunyian, dan mengamati kondisi sosial untuk kepentingan mereka (Horwarth, 2012). Wolfe \& Hermanson (2004) menjelaskan bahwa perubahan direksi sebagai wujud adanya conflict of interest. Perubahan direksi menjadi salah satu faktor pendorong terjadinya financial statement fraud karena dampak perubahan tersebut menjadi upaya manajemen dalam memperbaiki hasil dari kinerja direksi sebelumnya seperti merubah struktur organisasi perusahaan atau perekrutan direksi baru yang dianggap memiliki kemampuan lebih yang bagus dari direksi sebelumnya. Berdasarkan uraian tersebut maka hipotesis yang diajukan adalah:

H4: Change of directors berpengaruh terhadap financial statement fraud 


\section{e. Arogansi (arrogance) dan Financial Statement} Fraud

Arogansi dijelaskan sebagai sifat superioritas atas hak yang dimiliki dengan menganggap bahwa pengendalian internal dan kebijakan perusahaan tidak berlaku bagi dirinya (Horwarth, 2012). COSO menemukan bahwa $70 \%$ pelaku penipuan memiliki profil yang menampilkan kombinasi tekanan dengan arogansi dan keserakahan. Sebanyak $89 \%$ kasus penipuan melibatkan CEO (Nindito, 2018). Frequent number of CEO's picture merupakan jumlah gambar atau foto seorang CEO dalam suatu perusahaan pada laporan tahunan perusahaan (Yusof, A.H, \& Simon, 2015)CEO (Tessa \& Harto, 2016). Hal ini dilakukan karena mereka tidak ingin kehilangan posisi atau status yang dimiliki dalam lingkup manajemen perusahaan. Hasil penelitiannya menunjukkan bahwa adanya hubungan Frequent number of CEO's picture dengan arogansi terhadap tindakan financial statement fraud. Berdasarkan uraian tersebut rumusan hipotesis yang diajukan adalah:

H5: Frequent number of CEO's picture berpengaurh terhadap financial statement fraud

\section{Kecurangan Laporan Keuangan (Financial Statement Fraud)}

Kecurangan laporan keuangan merupakan kelalaian dan kesalahan dengan unsur kesengajaan dalam membuat laporan keuangan dengan penyajian yang tidak sesuai dengan prinsip akuntansi umumnya. Hal-hal yang termasuk Fraud seperti penyalahgunaan aset, korupsi, dan kecurangan laporan keuangan (Financial Statement Fraud).

\section{METODE PENELITIAN}

Penelitian ini menggunakan metode kuantitatif dengan populasi dalam penelitian ini yaitu perusahaan yang terdaftar dalam Jakarta Islamic Index (JII) tahun 2016-2018. Pemilihan populasi perusahaan yang terdaftar dalam Jakarta Islamic Index dengan pertimbangan untuk menganalisis pengaruh teori fraud pentagon dalam perusahaan Islamix Index terhadap praktik financial statement fraud yang berupa earning management. Pengambilan sampel penelitian diperoleh menggunakan metode purposive sampling dengan kriteria yaitu perusahaan yang konsisten terdaftar di Jakarta Islamic Index (JII) periode 2016-2018, dan perusahaan yang menyajikan laporan keuangan secara lengkap dalam nomimal Rupiah (Rp) sesuai dengan data yang dibutuhkan dalam variabel penelitian periode 2016-2018.

Tabel 1 Pengukuran Variabel

\begin{tabular}{|c|c|c|}
\hline $\begin{array}{c}\text { Faktor Risiko } \\
\text { Fraud }\end{array}$ & Kategori & Pengukuran \\
\hline Pressure & $\begin{array}{l}\text { Financial } \\
\text { Stability }\end{array}$ & 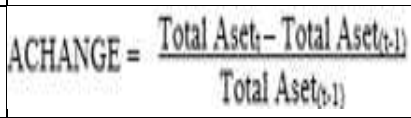 \\
\hline Opportunity & $\begin{array}{l}\text { Quality of } \\
\text { External } \\
\text { Audit }\end{array}$ & $\begin{array}{l}\text { Variabel dummy, apabila } \\
\text { mengggunakan jasa audit } \\
\text { KAP BIG4 diberi kode 2, } \\
\text { dan kode } 1 \text { jika tidak } \\
\text { menggunakan KAP } \\
\text { BIG4. }\end{array}$ \\
\hline Rationalization & $\begin{array}{l}\text { Change in } \\
\text { auditor }\end{array}$ & $\begin{array}{l}\text { Variabel dummy, apabila } \\
\text { terdapat pergantian } \\
\text { Kantor Akuntan Publik } \\
\text { selama periode 2016- } \\
2018 \text { maka diberi kode 2, } \\
\text { jika sebaliknya diberi } \\
\text { kode } 1 .\end{array}$ \\
\hline Competence & $\begin{array}{l}\text { Change of } \\
\text { directors }\end{array}$ & $\begin{array}{l}\text { Variabel dummy, kode } 2 \\
\text { jika terdapat perubahan } \\
\text { direksi } \\
\text { perusahaan, kode } 1 \text { jika } \\
\text { sebaliknya. }\end{array}$ \\
\hline Arrogance & $\begin{array}{l}\text { Frequent } \\
\text { number of } \\
\text { CEO's } \\
\text { picture }\end{array}$ & $\begin{array}{l}\text { Jumlah display picture } \\
\text { atau foto, mengenai } \\
\text { Direktur utama atau } \\
\text { CEO yang terpampang } \\
\text { secara berulang-ulang } \\
\text { dalam laporan tahunan } \\
\text { perusahaan. }\end{array}$ \\
\hline
\end{tabular}

Sumber : hasil olahan sendiri

Data yang digunakan dalam penelitian adalah data sekunder yaitu annual report perusahaan pada periode 2016-2018. Pengumpulan data dilakukan dengan teknik dokumentasi yaitu dengan mengunduh annual report perusahaan yang terdapat pada situs web perusahaan. Analisis data yang digunakan untuk menguji hubungan antara Discretionary accruals dan proksi dari fraud pentagon dengan menggunakan model regresi.

Discretionary Accruals (DAit) diperoleh dengan terlebih dahulu menghitung total akrual perusahaan i pada tahun $t$ dengan metode modified Jones (Dechow dkk., 1995 dalam Ujiyantho dan Pramuka, 2007).

$\mathrm{TAC}=\mathrm{N}_{\mathrm{it}}-\mathrm{CFO}_{\mathrm{it}}$ 
Dimana, TAC adalah total akrual, $\mathrm{N}_{\mathrm{it}}$ merupakan laba bersih perusahaan pada tahun tersebut, dan $\mathrm{CFO}_{\text {it }}$ adalah arus kas operasi.

Kemudian, mengestimasi nilai total accrual (TA) menggunakan persamaan regresi OLS sebagai berikut:

$\mathbf{T A}_{\mathrm{it}-1} / \mathbf{A}_{\mathrm{it}-1}=\boldsymbol{\beta}\left(\mathbf{1} / \mathbf{A}_{\mathrm{it}-1}\right)+\boldsymbol{\beta}\left(\Delta \operatorname{Rev}_{\mathrm{t}} / \mathbf{A}_{\mathrm{it}-1}\right)+\boldsymbol{\beta}\left(\mathbf{P P E}_{\mathrm{t}} / \mathbf{A}_{\mathrm{it}-}\right.$

$$
\text { 1) }+\mathrm{e}
$$

Keterangan:

$\mathrm{TA}_{\mathrm{it}-1}=$ Total akrual perusahaan i pada tahun $\mathrm{t}$

$\mathrm{A}_{\mathrm{it}-1}=$ Total aktiva perusahaan i pada tahun $\mathrm{t}$

$\Delta \operatorname{Rev}_{\mathrm{t}}=$ Perubahan pendapatan perusahaan $\mathrm{i}$ pada tahun $\mathrm{t}$

$\mathrm{PPE}_{\mathrm{t}}=$ Aktiva tetap perusahaan i pada tahun $\mathrm{t}$

NDA $_{\text {it }}=$ Non Discretionary Accruals perusahaan $\mathrm{i}$ pada tahun $\mathrm{t}$

$\mathrm{DA}_{\mathrm{it}}=$ Discretionary Accruals perusahaan i pada tahun $\mathrm{t}$

Maka, model regresi yang dibangun adalah sebagai berikut.

DAit $=\beta 0+\beta 1$ ACHANGE $+\beta 2$ AUD $+\beta 3 C P A+$ $\beta 4 D C H A N G E+\beta 5 C E O P I C+\varepsilon$

Keterangan:

$$
\begin{aligned}
\beta 0 & =\text { Koefisien regresi konstanta } \\
\beta 1,2,3,4,5= & \text { Koefisien regresi masing-masing } \\
& \text { proksi } \\
= & \begin{array}{l}
\text { Discretionary accruals pada } \\
\text { perusahaan i periode } \mathrm{t}
\end{array} \\
\text { DAit } & \text { Rasio perubahan total aset tahun } \\
& 2016-2018 \\
\text { ACHANGE } & \text { Kualitas auditor eksternal } \\
\text { AUD }= & \text { Pergantian auditor independen } \\
\text { CPA } & \text { Pergantian direksi } \\
\text { DCHANGE }= & \text { Jumlah foto CEO dalam laporan } \\
\text { CEOPIC }= & \text { keuangan } \\
\varepsilon & \text { error }
\end{aligned}
$$

\begin{tabular}{|c|c|c|c|c|c|}
\hline & $\mathrm{N}$ & Min & Max & Mean & Std. Dev \\
\hline$\overline{\mathrm{DA}}$ & 42 &,- 7945 & \multicolumn{3}{|c|}{,4377 -,045002,1920707 } \\
\hline ACHANGE & 42 & 0000 & 0003 & \multicolumn{2}{|c|}{,000046,0000527 } \\
\hline AUD & 42 &,- 299 & 335 & \multicolumn{2}{|c|}{,07374, 112378 } \\
\hline CPA & & 11,025 & 23,066 & \multicolumn{2}{|c|}{,424484,128022 } \\
\hline DCHANGE & 42 &, 015 & 24,061 & \multicolumn{2}{|c|}{$1,799775,325019$} \\
\hline CEOPIC & 42 & 2,000 & 7,000 & \multicolumn{2}{|c|}{$3,452381,016987$} \\
\hline $\begin{array}{l}\text { Valid N } \\
\text { (listwise) }\end{array}$ & 42 & & & & \\
\hline
\end{tabular}

\section{HASIL DAN PEMBAHASAN}

\subsection{Statistik Deskriptif}

Populasi penelitian terdiri dari semua perusahaan yang terdaftar di Jakarta Islamic Index (JII) pada tahun 2016 sampai 2018, terdapaat sebanyak 30 perusahaan. Bredasarkan kriteria pemilihan sampel, maka didapat 14 perusahaan yang terpilih menjadi sampel. Dari jumlah tersebut sampel yang diteliti

\begin{tabular}{|c|c|c|c|c|c|}
\hline \multicolumn{6}{|c|}{ Coefficients ${ }^{a}$} \\
\hline & & & $\begin{array}{c}\text { Standar } \\
\text { dized } \\
\text { Coeffici }\end{array}$ & \multirow{3}{*}{$\mathrm{t}$} & \multirow{3}{*}{ Sig. } \\
\hline & \multicolumn{2}{|c|}{ d Coefficients } & $\begin{array}{c}\text { Coeffici } \\
\text { ents }\end{array}$ & & \\
\hline Model & $\mathrm{B}$ & $\begin{array}{l}\text { Std. } \\
\text { Error }\end{array}$ & Beta & & \\
\hline 1 (Constant) & 1,243 & ,616 & & 2,016 &, 051 \\
\hline ACHANGE & ,747 &, 334 & ,402 & 2,237 &, 032 \\
\hline AUD &,- 294 & , 192 &,- 269 & $-1,532$ &, 134 \\
\hline $\mathrm{CPA}$ &,- 199 & ,238 &,- 182 &,- 837 &, 408 \\
\hline DCHANGE &,- 303 &, 111 &,- 365 & $-2,733$ &, 010 \\
\hline CEOPIC &, 003 & ,095 & ,005 & ,033 & ,974 \\
\hline
\end{tabular}
selama tiga tahun, maka didapat total sampel sebanyak 42 sampel.
Tabel 2

Descriptive Statistics

Sumber : Hasil Olahan SPSS 25

\subsection{Uji Regresi Linier Berganda}

Untuk menguji hipotesis yang digunakan dalam penelitian, perlu dilakukan uji regresi linear berganda, dimana pengujian ini untuk melihat pengaruh variabel independen terhadap dependen.

a. Uji Parsial (Uji t)

Tabel 3. Hasil Uji Regresi Lineaar Berganda

a. Dependent Variable: DACIT

Sumber: Hasil Olahan SPSS.

Berdasarkan hasil pada tabel 3, pengujian hipotesis yang didapatkan adalah sebagai berikut.

1) Berdasarkan hasil pengujian hipotesis, nilai t pada variabel ACHANGE sebesar 2,237 dengan nilai probabilitas signifikan sebesar $0,032<0,05$, maka dapat disimpulkan bahwa terdapat pengaruh antara variabel ACHANGE terhadap DA atau H1 diterima. Penelitian ini membuktikan hipotesis bahwa perusahaan yang tidak mempunyai stabilitas keuangan akan melakukan kecurangan dalam laporan keuangan perusahaan, sebab hal tersebut menjadi tekanan bagi perusahaan. Untuk mencapai stabilitas keuangan, perusahaan dapat 


\section{Jurnal Ilmiah Ekonomi Islam, 7(02), 2021, 1081}

meningkatkan atau menurunkan nilai aset perusahaan menggunakan metode akuntansi seperti mekanisme nilai wajar dan kapitalisasi aset (Albercht, 2002). Pertumbuhan aset perusahaan dapat digunakan sebagai tolak ukur perusahaan. Hasil penelitian ini juga telah dibuktikan oleh Sihombing \& Rahardjo (2014); Apriliana \& Agustina (2017) bahwa perusahaan yang tidak memiliki kestabilan keuangan akan berpotensi melakukan kecurangan laporan keuangan

2) Hasil pengujia hipotesis menunjukkan nilai t pada variabel AUD sebesar -1,532 dengan nilai probabilitas signifikan sebesar 0,134. Pada nilai signifikan t menunjukkan nilainya lebih besar dari $\alpha=0,05$, maka dapat disimpulkan bahwa tidak terdapat pengaruh antara variabel AUD terhadap DA atau $\mathbf{H 2}$ ditolak. Ini membuktikan bahwa peluang perusahaan dalam melakukan kecurangan laporan keuangan dengan menggunakan jasa auditor eksternal yang berkualitas tidak memiliki pengaruh dalam mendeteksi kecurangan laporan keuangan. Hal ini menjelaskan bahwa penggunaan auditor eksternal BIG4 yang berkualitas tidak menjadi jaminan output yang dihasilkan lebih baik dari KAP non BIG4 dalam mendeksi adanya laporan keuangan yang dimanipulasi. Dengan kata lain, penggunaan KAP BIG4 dan non BIG4 samasama mempunyai peran dalam melakukan audit dan menentukan kekeliruan yang terjadi pada laporan keuangan berdasarkan ketentuan akuntansi yang berlaku, sehingga kualitas auditor eksternal tidak berpengaruh terhadap pengungkapan kemungkinan terjadi kecurnagan laporan keuangan. Hasil ini memperkuat penelitian yang telah dilakukan Setiawati \& Baningrum (2018) dan Rahman \& Nurbaiti (2019).

3) Nilai t pada variabel CPA sebesar -0,837 dengan nilai probabilitas signifikan sebesar 0,408. Pada nilai signifikan $\mathrm{t}$ menunjukkan nilainya lebih besar dari $\alpha=0,05$, maka dapat disimpulkan bahwa tidak terdapat pengaruh antara variabel CPA terhadap DA atau $\mathbf{H 3}$ ditolak. Ini berarti perusahaan yang melakukan perubahan auditor eksternal tidak berpengaruh terhadap manipulasi financial statement. Studi terdahulu dari Skousen (2008) yang menunjukkan bahwa perusahaan yang melakukan pergantian auditor eksternal dianggap untuk menghilangkan jejak penipuan dari auditor sebelumnya dan memungkinkan perusahaan untuk mengganti auditor yang mana hipotesis tersebut terbantah dalam penelitian ini. Padahal, pergantian auditor eksternal dapat disebabkan oleh kemungkinan adanya ketidakpuasan perusahaan terhadap kinerja auditor eksternal sebelumnya. Selain itu, adanya peraturan pemerintah No. 20 tahun 2015 tentang maksimum penggunaan jasa audit eksternal selama 5 tahun berturut-turut, sehingga pergantian auditor eksternal juga sebagai bentuk dari kepatuhan terhadap peraturan yang ada. Hasil ini juga didukung oleh penelitian yang dilakukan oleh Sihombing \& Rahardjo (2014); Tessa \& Harto (2016); Apriliana \& Agustina (2017).

4) Pengujian hipotesis menghasilkan nilai $t$ pada variabel DCHANGE sebesar -2,733 dengan nilai probabilitas signifikan sebesar 0,010. Pada nilai signifikan t menunjukkan nilainya lebih besar dari $\alpha=0,05$, maka dapat disimpulkan bahwa terdapat pengaruh antara variabel ACHANGE terhadap DA atau $\mathrm{H4}$ diterima. Artinya, perubahan direksi sebagai indikator kompetensi tidak mempunyai pengaruh terhadap kecurangan laporan keuangan. Meskipun, perubahan direksi yang sering dilakukan oleh perusahaan cenderung memiliki efek stress period yang akan berdampak terhadap keterbukaan peluang untuk melakukan kecurangan laporan keuangan ternyata belum tentu benar. Perubahan direksi tersebut bisa disebabkan oleh adanya perbaikan kinerja direksi lama dengan direksi baru yang dianggap lebih kompeten dibidang tersebut, sehingga kinerja yang dihasilkan akan lebih maksimal. Hasil ini juga selaras dengan penelitian Apriliana dan Agustina (2017).

5) Nilai $t$ pada variabel CEOPIC sebesar 0,033 dengan nilai probabilitas signifikan sebesar 0,974. Pada nilai signifikan $\mathrm{t}$ menunjukkan nilainya lebih kecil dari $\alpha=0,05$, maka dapat disimpulkan bahwa tidak terdapat pengaruh antara variabel CEOPIC terhadap DA atau $\mathbf{H 5}$ ditolak. Artinya, jumlah foto CEO yang ditampilkan dalam laporan tahunan tidak memiliki efek dalam mendeteksi kecurangan laporan keuangan. Hasil ini disebabkan bahwa hampir seluruh perusahaan yang digunakan sebagai sampel penelitian menampilkan foto CEO untuk melengkapi format formalitas dalam laporan tahunan yaitu memperkenalkan siapa CEO di perusahaan dan keterlibatannya dalam perusahaan tersebut sehingga jumlah penampakan gambar CEO pada setiap perusahaan sama, sehingga ini 
tidak dapat digunakan sebagai sebuah faktor untuk mengindikasi adanya kecurangan laporan keuangan. Hasil ini juga didukung oleh studi terdahulu yang dilakukan oleh Ulfah, dkk (2017).

\section{b. Uji Simultan (Uji F)}

\section{Tabel 8. Uji Simultan ANOVA ${ }^{\mathrm{a}}$}

\begin{tabular}{llr|r|r|r|r} 
& Model & $\begin{array}{c}\text { Sum of } \\
\text { Squares }\end{array}$ & df & $\begin{array}{c}\text { Mean } \\
\text { Square }\end{array}$ & F & Sig. \\
\hline 1 & Regression &, 459 & 5 &, 092 & 4,488 &, $003^{\mathrm{b}}$ \\
\cline { 2 - 6 } & Residual &, 736 & 36 &, 020 & & \\
\hline Total & 1,195 & 41 & & & \\
\hline
\end{tabular}

a. Dependent Variable: DACIT

b. Predictors: (Constant), CEOPIC, DCHANGE, AUD, ACHANGE, CPA

Sumber: Hasil olahan SPSS.

Pada uji simultan (Uji F) hasil yang ditunjukkan pada tabel 8 yaitu nilai signifikan dari $\mathrm{F}$ adalah 0,003 dan menunjukkan nilai $\mathrm{F}$ lebih besar dari $\alpha=0,05$, maka dapat disimpulkan bahwa ACHANGE, AUD, CPA, DCHANGE dan CEOPIC secara simultan berpengaruh terhadap Discreationary Accruals (DA).

\section{KESIMPULAN}

Berdasarkan hasil analisis deskriptif dan uji asumsi klasik diperoleh kesimpulan bahwa secara simultan kecurangan laporan keuangan dapat dipengaruhi oleh pressure (tekanan), opportunity (peluang), rationalization (rasionalisasi), competence (kemampuan) dan arrogance (arogansi). Secara parsial, dari lima hipotesis yang diajukan, hanya tiga hipotesis yaitu tekanan dan kompetensi yang memiliki pengaruh terhadap kecurangan laporan keuangan, sedangkan peluang, rasionalisasi, dan arogansi tidak memiliki pengaruh terhadap kecurangan laporan keuangan. Penelitian selanjutnya diharapkan bisa memperpanjang tahun penelitian, mengganti atau menambah proksi atau hopitesis yang mewakili masing-masing elemen, atau pengembangan menggunakan metode lain seperti F-Score.

\section{DAFTAR PUSTAKA}

Apriliana, S., \& Agustina, L. (2017). The Analysis of Fraudulent Financial Reportingg Determinant through Fraud Pentagon Approach. Jurnal Dinamika Akuntansi (JDA), 154-165.
Association of Certified Fraud Examiners. (2016). Report to the nation on occupational fraud and abuse (2016 global fraud study). Diambil dari www.acfe.com/rttn/rttn-2016.pdf.

Cressey, D. R. (1953). Other people's Money: A study of the social psychology of embezzlement. Glencoe, IL: Free Press.

Horwarth, C. (2012). The Mind Behind The Fraudsters Crime:Key Behavioral and Environmental Element. Diambil dari https://www.google.com/url?sa=t\&rct=j\&q=\&es $\mathrm{rc}=\mathrm{s} \&$ source $=$ web $\& \mathrm{~cd}=1 \& \mathrm{cad}=\mathrm{rja} \&$ uact $=8 \& \mathrm{ve}$ $\mathrm{d}=2$ ahUKEwjqwenx $5 \mathrm{cXlAhVTg}$ -

YKHYicAn0QFjAAegQIARAC\&url=http\%3A $\% 2 \mathrm{~F} \% 2 \mathrm{Fwww}$.fraudconference.com\%2Fupload edFiles\%2FFraud_Conference $\% 2$ FContent $\% 2 \mathrm{~F}$ Course-

Materials $\% 2$ Fpresentations $\% 2 \mathrm{~F} 23 \mathrm{rd} \% 2 \mathrm{Fppt} \% 2$ F10C-Jonathan-

Marks.pdf\&usg=AOvVaw0vPLBmOme52j5Yyt UUY9iJ

Jensen, M. C., \& Meckling, W. H. (1976). Theory of the firm: Managerial Behavior Agency Costs and Ownership Structure. Journal of Financial Economics, Vol. 3 No.4.

Lesmana, A. S. (2019, Juli). Manipulasi Laporan Keuangan, Dirut Garuda Didesak Segera Dicopot. Diambil 28 Oktober 2019, dari https://www.suara.com/bisnis/2019/07/02/20080 7/manipulasi-laporan-keuangan-dirut-garudadidesak-segera-dicopot

Marks, J. (2012). The Mind Behind The Fraudsters Crime: Key Behavioral and Environmental Elements Discussion Leader: Crowe Horwarth. Crowe Horwarth.

Nindito, M. (2018). Financial Statement Fraud: Perspective of The Pentagon Fraud Model in Indonesia. Academy of Accounting and Financial Studies Journal, Volume 22(2), 1-9.

Pamungkas, I. D., \& Utomo, St. D. (2018). Fraudulent Financial Reporting: An Application of Fraud Pentagon Theory to Association of Southeast Asian Nations Corporate Governance Scorecard. Journal of Advanced Research in Law and Economics, Vomune IX(5(35)), 1729-1737. https://doi.org/10.14505/jarle.v9.5(35).26 
Rahman, A. A., \& Nurbaiti, A. (2019). Analisis Faktor-Faktor yang Mempengaruhi Kecurangan Laporan Keuangan dalam Perspektif Fraud Pentagon (Studi pada Perusahaan Sektor Infrastruktur, Utilitas dan Transportasi yang Terdaftardi Bursa Efek Indonesia Tahun 20162017). Journal Accounting and Finance, Vol. 3 No. 2, 34-44.

Setiawati, E., \& Baningrum, R. M. (2018). Deteksi Fraudulent Financial Reporting Menggunakan Analisis Fraud Pentagon: Studi Kasus pada Perusahaan Manufaktur yang Listed di BEI Tahun 2014-2016. Riset Akuntansi dan Keuangan Indonesia, 91-106.

Siddiq, F. R., Achyani, F., \& Zulfikar, Z. (2017). Fraud Pentagon Dalam Mendeteksi Financial Statement. The 4th Call for Syariah Paper, 1-14. Sihombing, K. S., \& Rahardjo, S. N. (2014). Analisis Fraud Diamond dalam Mendeteksi Financial Statement Fraud": Studi Empiris Pada Perusahaan Manufaktur yang Terdaftar di Bursa Efek Indonesia (BEI). Journal of Accounting.

Skousen, C. (2008). Detecting and Predicting Financial Statemen Fraud: The Effectiveness of the Fraud Triangle and SAS No. 99. Journal of Accounting and Auditing, 13, 53-81.

Spatish, T. C. (2002). Detecting False Financial Statements Using Published Data: SomeEvidence from Greece. Managerial Auditing Journal, Vol. 17.
St. Pierre, K., \& Anderson, J. A. (1984). An Analysis of The Factors Associated With Lawsuits Against Public Accountants. The Accounting Review, 242-263.

Stice, J. D. (1991). Using Financial and Market Information to Identify Preengagements Factors Associated with Lawsuits Against Auditors. The Accounting Review, 516-533.

Tessa, C., \& Harto, P. (2016). Fraudulent Financial Reporting: Pengujian Teori Fraud Pentagon Pada Sektor Keuangan dan Perbankan di Indonesia. Simposium Nasional Akuntansi XIX.

Ulfah, M., Nuraina, E., \& Wijaya, A. L. (2017). Pengaruh Farud Pentagon dalam Mendeteksi Farudulent Financial Reporting (Studi Empiris pada Perbankan di Indonesia yang Terdaftar di BEI). The 9th FIPA (Forum Ilmiah Pendidikan Akuntansi), Vol 5 No 1, 399-418.

Wolfe, D. T., \& Hermanson, D. R. (2004). The Fraud Diamond: Considering the Four Elements of Fraud. CPA Journal, 74.12, 38-42.

Yusof, M. K., A.H, A. K., \& Simon, J. (2015). Fraudulent Listed Companies. he Macrotheme Review, 4(3). 